\title{
THE IMPLICATIONS OF FEDERALISM FOR INDIGENOUS AUSTRALIANS
}

\section{Cheryl Saunders}

Australian federalism is a by-product of the manner in which the Australian state was created in 1901, through the voluntary amalgamation of six self-governing British colonies, each with its own constitution, institutions and laws. For its critics, the federal system is kept in place largely by habit and entrenched interests. More objectively, however, a federal form of government still plays an important role in Australia. Decentralised government of some kind is dictated by geographic size. By offering a more local level of government, federalism thus contributes, at least potentially, to Australian democracy. In the absence of other significant constitutional constraints, including protection of rights, federalism provides a check on public power. Indeed, given Australia's adherence to the British constitutional tradition, had a normative constitution not been necessitated by the introduction of a federal system, it is doubtful that Australia would have had one at all.

Australian federalism plays no role in moderating competing ethnic demands. For the first fifty years after federation, the Australian population overwhelmingly, although not exclusively, was Anglo-Celtic in composition. Successive waves of migration following World War II, initially from Europe and more recently from Asia, have created a multi-ethnic people, but in a way that has no particular implications for the federal system. There is no concentration of discrete groups in different parts of Australia. Multicultural policies are disputed, but no one seeks to resolve the dispute through the application of federal principles, in the sense of providing forms of self-government for particular ethnic groups. The policy demands of new immigrant groups are limited to more effective protection against discrimination, to facilitation of the use of community languages and preservation of community cultures, and to immigration 
programs more conducive to family reunion. Immigrants have come to Australia voluntarily and, for the most part, they accept that any changes that they seek can be effected within the framework of the existing governance arrangements, which attracted them to Australia in the first place.

The position of the indigenous people of Australia is quite different. Despite the legal fiction of terra nullius, an estimated 700,000 indigenous people inhabited the Australian mainland and surrounding islands when the British claimed sovereignty from 1770 (Gardiner-Garden 1994:8). Their ancestors had inhabited Australia for an estimated 50,000 years. They spoke up to 300 different languages and lived in hundreds of tribal groupings. They had their own systems of law and custom and their own established authority structures. And each group had a special relationship with its own part of the land

\begin{abstract}
... which defies definition. It is best described as a continuing dynamic notion, not bounded by geographical limits of a surveyor. It is a living, breathing entity made up of earth, sky, clouds, rivers, trees, rocks and the spirits sent by the Big One above to create all these things. It is the place wherein the spirits of our forefathers roam. The place wherein our spirits will reside on our return to the golden Corroboree ground, the Dream Time. Earth is an extension of our very souls, it is our everything. I repeat, it is our everything. (Bonner 1994:viii)
\end{abstract}

The British claimed sovereignty over Australia as a settled colony. There was no act of acquiescence on the part of the indigenous people, and no acknowledgement of conquest at the time or later. British law was introduced to the exclusion of indigenous law, at least in theory. The indigenous peoples were decimated, through deliberate slaughter and disease. Those in the southern, more settled parts of the country were progressively dispossessed of their lands. As they moved towards the north and west, they intruded on to the lands of others, causing further confusion and conflict.

By the latter part of the twentieth century, indigenous Australians constituted approximately 1.5 per cent of the total Australian population. They were grievously disadvantaged, economically and socially. On the face of it, they were in no position to exercise political influence. But the context was changing. In the wake of the rights revolution and of the decolonisation that followed World War II came a new understanding of the nature of indigenous communities, the depth of their heritage and their relationship with the land. Indigenous groups organised; non-indigenous Australians became increasingly ashamed of past repressive policies and continuing cultural, economic and social deprivation; the international community brought pressure to bear. More enlightened policies fuelled demands for rights to land, culturally sensitive administration, and 
non-indigenous recognition of indigenous laws and customs. For the first time, Australia confronted the presence of a different ethnicity, claiming original occupation and demanding a right at least to share the country.

The Australian experience is relevant to the theme of this book for this reason. This chapter explores the extent to which Australian federalism has helped or hindered the resolution of differences between indigenous and non-indigenous Australians. The result throws some light on the circumstances in which federalism may assist with ethnic tension and helps to explain the dynamics of federalism itself.

The most obvious way in which federalism might assist to resolve ethnic issues of this kind is by offering indigenous peoples opportunities for self-governance as a constituent part of the federation, geographically defined. There is a partial precedent in Australia, in Norfolk Island. Under current legislation, the territory has substantial local autonomy and some immunity from Commonwealth law in recognition of the 'special relationship' of its inhabitants to the island and 'their desire to preserve their traditions and culture' (preamble to Norfolk Island Act 1979). Proposed changes to this regime, which would extend the right to vote to all Australian citizens resident on Norfolk Island, suggest that this example is unlikely to be used more widely (Norfolk Island Amendment Bill 1999). Even without such a structural solution, however, federalism might be expected to encourage greater tolerance of diversity of policies and law and greater understanding of the desire of communities to make their own decisions. Similarly, long-standing acceptance of different legal regimes in the different States might be acknowledged as a precedent for the use by indigenous groups of their own customary law.

Institutionally, federalism offers opportunities to deal constructively with ethnicity as well. A special relationship between a national government and the indigenous people, to the exclusion of sub-national governments, as in the United States, offers a means of recognising the unique status of indigenous peoples without jeopardising the integrity of the state as a whole (Kickingbird 1993:12). Alternatively, if indigenous people are subject to State laws, an opportunity arises to experiment with new approaches, in more receptive parts of the country, without a need to persuade the entire national polity. In another variation, bodies which are representative of the components of the federation, such as an upper chamber of the national legislature or the meeting of heads of government, might be extended to embrace representation of indigenous people as well.

With relatively minor exceptions, however, the Australian federal system has not contributed to the resolution of indigenous issues in these or other ways. While there is now a limited measure of indigenous self-administration and limited recognition of customary law, in neither case has the federal system played a significant role. To substantiate and help to explain 
this claim, the next two parts of this chapter examine the position of the indigenous people within the federal system, both generally and with particular reference to self-government or self-determination.

It shows that, despite the federal system, Australian constitutional culture is not hospitable to indigenous issues. Dominant competing influences are majoritarian decision making, formal equality and parliamentary sovereignty within the framework of a not particularly restrictive constitution. Australia is firmly in the Western liberal tradition in its adherence to individual rather than collective rights. Even individual rights, however, are not protected by the constitution but solely by the common law and occasional statutes. The practical consequences of this were brought home to the indigenous people in 1997 in Kruger v. Commonwealth, in which the High Court rejected all grounds of challenge to the forcible removal of Aboriginal children from their parents in the Northern Territory between 1925 and $1949 .{ }^{1}$

It may be that the potential of the federal system to deal with indigenous matters has not yet been realised. Opportunities for it to play a greater role were suggested by two separate developments in the approach to the centenary of federation in 2001. The first is projected statehood for the Northern Territory. The second is the movement for reconciliation. The final part of the chapter explores both of these.

\section{THE FEDERAL DIVISION OF POWER}

Australia became a federation in 1901. The constitution was written over the preceding decade. It drew on both the British and US constitutional models. From Britain came the parliamentary system with which the colonies were already familiar and the constitutional culture associated with it, hostile to limits on the power of parliament except to the minimum necessary extent. From the United States came federalism and its accoutrements of a written constitution representing fundamental law, enforced through independent courts. A powerful upper house of the Australian parliament, loosely modelled on the US Senate, comprised equal numbers of senators from each of the original States, directly elected by the voters of those States (s. 7). In time, the Senate would be elected on the basis of a system of proportional representation, producing a chamber in which minority parties generally hold the balance of power (Coonan 1999:107). The constitution could be amended only by referendum, which required approval by double majorities (s. 128), nationally and in the majority of States.

Australia also followed the United States in the manner of distributing powers between the new national level of government (the Commonwealth) and the sub-national units (the States). The constitution lists national powers (s. 51). Those not listed, by inference, remain with the 
States. Most Commonwealth powers are concurrent, in the sense that the States can exercise them as well. In the event of a conflict, however, valid Commonwealth legislation prevails (s. 109). In a departure from the US system, the Australian constitution provided also for the establishment of a High Court, as the final court of appeal in matters of State as well as federal jurisdiction. This enabled the emergence of a common law that was uniform across the country.

The indigenous people unambiguously fell within the authority of the States in 1901. They were specifically excluded from Commonwealth power to legislate with respect to 'the people of any race ... for whom it is deemed necessary to make special laws' (s. 51(26)). In addition, the constitution provided that 'in reckoning the numbers of the people of the Commonwealth or of a State ... aboriginal natives shall not be counted' (s. 127). This latter provision excluded the indigenous people from calculations required under the constitution to determine State revenue redistribution and the allocation of seats between the States in the House of Representatives. It further reinforced their political insignificance and may be a factor that contributed to their historic economic disadvantage.

The first Commonwealth franchise enacted in 1902 reinforced the effects of exclusion from the constitution by denying the vote to indigenous people, unless already held under the law of a particular State when the constitution came into effect (s. 41). While State practice varied, Western Australia and Queensland, the States with the largest populations of indigenous people, did not recognise their right to vote, and there is some evidence that Aboriginals who held the vote under s. 41 of the constitution were struck off the roll by Commonwealth electoral officials (Chesterman and Galligan 1997:89). In other respects as well, indigenous Australians were denied rights enjoyed by the wider community (Gardiner-Garden 1994:10).

Most powers likely to impinge on the interests of indigenous people were left to the States by the constitution. These included education, housing, health, police and civil rights. Importantly, they also included land management and associated activities, including primary production and mining. The Crown in right of the several States held all land unless and until it was transferred to private ownership or acquired by the Commonwealth. Under the constitution, the Commonwealth could acquire property only on 'just terms', requiring fair compensation, with the courts as ultimate arbiter (s. 51(31)). The legal fiction that Australia was terra nullius was in place well before federation and left no room for the recognition of indigenous interests in land as a right, ${ }^{2}$ although some pastoral leases made explicit reservations for traditional Aboriginal use. ${ }^{3}$

The balance of power between the Commonwealth and the States with respect to indigenous people and the influence of indigenous 
people in the Australian constitutional system changed substantially over the course of the twentieth century, for a variety of distinct but interrelated reasons.

In 1911, the Northern Territory of South Australia was transferred to the Commonwealth under s. 122 of the constitution, which gives the Commonwealth power to legislate for territories, unrestricted by the federal provisions of the constitution. The transfer of jurisdiction was not immediately significant. Ultimately destructive policies of assimilation, including the forcible removal of indigenous children from their parents, were implemented in the Northern Territory as well, under Commonwealth auspices. In the early 1960s, however, the Commonwealth began to take steps to remove legal discrimination against indigenous people, including restrictions on the franchise (Commonwealth Electoral Act 1962, s. 2). And in 1976, land rights legislation enacted by the Commonwealth came into force in the Northern Territory, enabling Aboriginal groups to secure freehold title to existing reserves and to claim vacant Crown land, where traditional attachment could be established (Aboriginal Land Rights (Northern Territory) Act 1976). Statutory land rights initiatives were taken in most of the States as well: they were, however, 'limited and somewhat token ... one of the less noble facets of Australian parliamentary democracy' (Chesterman and Galligan 1997:205). National land rights legislation was not secured before the 1992 decision in Mabo (No. 2) recognised the survival of native title and forced legislation to manage the manner in which claims were made. ${ }^{4}$ The Aboriginal Land Rights (Northern Territory) legislation was still new when self-government was conferred on the Northern Territory in 1978. In a climate of doubt about whether a more independent Territory could be entrusted with an issue of such central concern to its minority indigenous peoples, the land rights regime stayed within Commonwealth control. ${ }^{5}$ This was and remains a point of distinction between the powers of the Territory and those of the States (Nicholson 1985:698, 706; see also Reeves 1998), and will be a contentious issue for decision if and when the Northern Territory achieves statehood.

The second major development was the referendum of 1967 . The referendum changed the constitution to remove the prohibition against including indigenous people in population calculations and, in effect, to give the Commonwealth concurrent powers with the States with respect to indigenous people. It was passed in all States, with an overall national vote of 92 per cent. Commonwealth power was extended by excising the reference to Aboriginal people from the so-called 'races' power, leaving it as a power to legislate with respect to 'the people of any race for whom it is deemed necessary to make special laws'. This was, as Justice Gaudron pointed out in Kartinyeri v. Commonwealth, a 'minimalist' approach to 
conferring power on the Commonwealth to legislate with respect to the Aboriginal people, the meaning of which was inherently ambiguous. No doubt its purpose was generally benevolent, although it is difficult to establish that specifically. ${ }^{6}$ The original head of power clearly had been intended to enable adverse discrimination, however, if the Commonwealth saw fit. There is nothing in the wording of the power, as amended, to suggest that it could not similarly be used in relation to the Aboriginal people as well.

This conflict was considered by the High Court in the Kartinyeri case. The case concerned the Aboriginal and Torres Strait Islander (Heritage Protection) Act 1984, which provided a measure of Commonwealth protection for areas or objects of special significance to indigenous people, where comparable State legislation failed to do so. After a protracted dispute over one such area, in the course of which a State Royal Commission found that the heritage claims were false, in the absence of evidence from the claimants, the Commonwealth parliament amended the legislation to exclude that claim from the operation of the Act. The claimants challenged the validity of the amending Act on the grounds that it was not for the benefit of Aboriginal people. The challenge was dismissed, principally on the ground that what parliament can enact it can repeal as long as, presumably, the law as changed could have been enacted under the power in the first place (Lindell 1998:273).

Although it was not necessary for the High Court to deal with the scope of the power itself, four of the six justices did so. One accepted that the power could not be used to enact laws that 'adversely and detrimentally' discriminate against people on the grounds of race (Kirby $\mathrm{J}: 765$, in Kartinyeri). Three others denied this limitation, while suggesting that there may nevertheless be outer limits on the use of the power, drawn from the requirement for parliament to deem it necessary to make special laws. Thus, Justices Gummow and Hayne suggested that a law might be invalid if there were a 'manifest abuse' of the judgment that it was necessary to make a special law or to make the particular special law under challenge, a criterion which one leading constitutional practitioner has equated with irrationality (Gageler 1998:270, 272). In similar vein, Justice Gaudron (736, in Kartinyeri) observed that it would be 'difficult to conceive of circumstances in which a law presently operating to the disadvantage of a racial minority would be valid'. One reference in the joint judgment of Gummow and Hayne JJ (743-4) also raised the possibility that the conception of the rule of law, in accordance with which the constitution is framed, might provide a further constraint on the exercise of the power (Lindell 1998:277). The implications of these vague but potentially significant limitations no doubt will be elaborated in the future, and even now offer a fertile field for the elaboration of theories about judicial 
method. On any view, however, they are likely to assist the subjects of Commonwealth legislation only in extreme circumstances.

The power conferred on the Commonwealth by the 1967 referendum is held concurrently with the States. The Commonwealth was slow to exercise it; and Commonwealth interest in taking a lead in indigenous affairs has fluctuated with successive governments. The States still retain primary responsibility for indigenous residents as members of State communities in areas of general State law, including health, housing, education and law enforcement. The number of indigenous residents is a factor taken into account by the Commonwealth Grants Commission in calculating fiscal equalisation entitlements, but the general revenue funds which States receive in consequence are not tied to purpose. The effects of these divided responsibilities have been criticised. In 1995, the Aboriginal and Torres Strait Islander Commission (ATSIC) highlighted the problems many indigenous people face with substandard housing, municipal infrastructure and services; health, as indicated by high rates of infant mortality, lower life expectancy and high rates of hospitalisation and disability; and education, for which they sought a curriculum which respects the values of both indigenous and non-indigenous Australians (ATSIC 1995:85-91). The report identified failures of intergovernmental cooperative programs as a major factor contributing to continuing social and economic disadvantage and proposed new national programs. Attention was also drawn to the still unresolved problems of the application of the criminal justice system to indigenous people. This had been the subject of a report by a Royal Commission into Aboriginal Deaths in Custody three years earlier, the recommendations of which still were not implemented, despite commitments by all Australian governments (ATSIC 1995:91-4).

A further major shift in the manner in which the Australian federal system relates to indigenous Australians came through the external affairs power.

At the time of federation, power to legislate with respect to 'external affairs' was conferred on the Commonwealth (s. 51(xxix)). Its significance was restricted by Australia's colonial status, which left the United Kingdom, as the imperial authority, to make international arrangements on behalf of Australia. In 1901, too, the scope of international law was more limited, particularly in relation to human rights and the environment. Australia gradually acquired the authority to make its own international treaties and ultimately achieved full independence by an evolutionary process, the precise culmination point of which is uncertain but was no later than $1942 .{ }^{7}$

The aftermath of World War II saw the implementation of international human rights instruments, to which Australia became a party, 
including the International Covenant on the Elimination of All Forms of Racial Discrimination. In 1975, relying largely on the external affairs power, the Commonwealth enacted a Racial Discrimination Act, making it 'unlawful to do any act involving a distinction based on race, which has the purpose or effect of nullifying or impairing the recognition, enjoyment or exercise on an equal footing, of any human right or fundamental freedom' (s. 9). Section 10 of the Act provided that

if by reason of a provision of a law of the Commonwealth or of a State or Territory, persons of a particular race do not enjoy a right that is enjoyed by persons of another race, or enjoy that right to a more limited extent, then by force of this section, those persons of the first-mentioned race shall enjoy that right to the same extent as people of other races.

The validity of the legislation was confirmed by the High Court in 1982, in the context of discrimination by the Queensland government against an Aboriginal group. ${ }^{8}$ The Koowarta case marked an important stage in the evolution of the interpretation of the external affairs power to the point where it authorises the Commonwealth parliament to legislate to implement any international treaty to which Australia is a party. This was a highly contentious development, because of its effect on the constitutional distribution of power between the Commonwealth and the States.

The Racial Discrimination Act played a key role in the litigation, which ultimately led the High Court to decide that, in some circumstances, native title had survived European settlement and would now be recognised by the common law.

The notion that Australia was terra nullius dated from the nineteenth century and, in particular, from a decision of the Privy Council confirming a long-standing assumption that Australia consisted of 'a tract of territory practically unoccupied without settled inhabitants'. ${ }^{9}$ In the 1970 s, encouraged by the more informed climate of understanding of indigenous culture and law in the latter half of the twentieth century, attempts were made to secure judicial recognition of indigenous rights to land, without success. ${ }^{10}$ In 1982, however, plaintiffs from a group of islands in the Torres Strait, formerly part of the State of Queensland since annexation in 1879, commenced proceedings in the High Court claiming ownership. The action was well chosen, in the sense that there had been no general European settlement of the island, apart from a small number of leases, and the islanders had lived on and cultivated land in a manner consistent with concepts of individual ownership. By comparison with indigenous people on the mainland, at least, it was relatively more straightforward for the islanders to establish historic possession. Even so, the High Court remitted the task of determining the facts to the 
Supreme Court of Queensland. This proved an elaborate proceeding and the substantive issues did not return to the High Court for determination until 1991. In the end, the tribunal in fact accepted some aspects of the claim, although not those of Eddie Mabo from whom the case takes its name. ${ }^{11}$

Meanwhile, in 1985, the Queensland parliament had enacted legislation retrospectively invalidating any native title that might still exist in relation to the island, with retrospective effect from the date of annexation, in 1879. The validity of this legislation was challenged in the High Court in 1988 in Mabo (No. 1), ${ }^{12}$ on the grounds of conflict with the Racial Discrimination Act. In upholding the challenge, the High Court accepted that the effect of the Queensland law was to give the islanders more limited rights than those of other Queenslanders, contrary to s. 10 of the Act. Henceforth, the Racial Discrimination Act was recognised as a significant constraint on State dealings with indigenous people. And while from the standpoint of the Commonwealth the Act has the formal status only of ordinary legislation, its significance is such that, de facto, it has become regarded as quasi-constitutional in character.

The substantive issues in the case ultimately were determined in 1992 in Mabo (No. 2). In a statement of principle that applied to mainland Australia as well as to the Torres Strait Islands, the High Court determined

that the common law of this country recognises a form of native title which, in the cases where it has not been extinguished, reflects the entitlements of the indigenous inhabitants in accordance with their laws and customs to their traditional land . . . ${ }^{13}$

Survival of title depended on a continuing traditional connection with the land by the clan or group concerned (Brennan J:59-60, in Mabo). It was not extinguished by European settlement itself, which conferred underlying or 'radical' title to land on the Crown. It would be extinguished, however, by a subsequent grant of interest in the land revealing 'a clear and plain intention to do so' (Brennan J:64). It followed that native title was clearly extinguished by grants of fee simple and leases that conferred exclusive possession, although there was some doubt about grants made after 1975, because of the operation of the Racial Discrimination Act. Other doubts, about whether pastoral leases conferred over vast tracts of land extinguished native title, were the subject of a later decision which confirmed that native title could continue on pastoral leases when it was capable of operating consistently with the terms of the lease. ${ }^{14}$

Mabo had a profound effect on the position of the indigenous people in the Australian constitutional system, including its federal arrangements. Recognition of native title, with its underlying recognition of Aboriginal society before European settlement, gave moral and psychological 
impetus to indigenous demands for legal, economic and social equality. It effected a change in State land law, which could not be reversed unless, at least, reversal could be achieved consistently with the Racial Discrimination Act. In fact, the conditions laid down in Mabo for a successful native title claim would be difficult to establish and almost impossible in the settled south of the country where 200 years of dispossession have broken the continuity of the links of most, if not all, groups with the land. The fact of the decision meant that claims would be made, however, whatever the outcome. This would be prolonged and expensive for Aboriginal claimants, if the ordinary courts were used. There would also be a period of uncertainty for parts of the non-indigenous community, including the powerful mining and pastoral industries, both in relation to grants of interests in land by the States after the Racial Discrimination Act came into effect and generally. These concerns ultimately spread to the community more widely, with exaggerated descriptions of the potential effects of $M a b o .^{15}$ Meanwhile, indigenous groups who were not in a position to claim title to traditional lands because of past dispossession sought compensation on grounds of equity.

These various considerations caused the Commonwealth to enact legislation, following consultation with Aboriginal leaders. The Native Title Act 1993 established a Native Title Tribunal as the primary forum for native title claims. It facilitated confirmation of the validity of different types of land grants between 1975 and 1993, which might otherwise have been inconsistent with the Racial Discrimination Act. In the case of past grants by the Commonwealth, the Act itself declared them valid. In the case of past Acts by States, the Act authorised validation by the State, subject to a requirement to pay compensation. It provided a framework within which future grants inconsistent with native title might be made, subject, among other things, to equality of treatment with non-native title holders. This generally involved compensation and, in some cases, a right to negotiate for native title holders, leaving failure to reach agreement to decision by the tribunal. The framework was exclusive and overrode inconsistent State law. The Act purported to leave intact the Racial Discrimination Act. To the extent to which it drew distinctions on the ground of race, it could be justified as a special measure consistently with the international covenant or characterised as a law that was not relevantly discriminatory. ${ }^{16}$ The Act also established a land fund to assist indigenous people to acquire land. It was expressed to operate retrospectively from June 1993.

Shortly before the Commonwealth legislation was passed, Western Australia enacted legislation of its own (Land (Titles and Traditional Usage) Act 1993), eliminating native title in that State in favour of a statutory 'right of traditional usage' and offering compensation for native title 
extinguished between 1975 and 1993 inconsistently with the Racial Discrimination Act. The Western Australian Act admittedly was inconsistent with the Native Title Act, if the latter were valid. There was a possible argument that it was inconsistent with the Racial Discrimination Act as well, on the grounds that, for example, rights of traditional usage were more easily extinguished than other forms of title in Western Australia.

Two suits, respectively seeking a declaration of the invalidity of the Commonwealth and Western Australian native title measures, were combined in the High Court. With one relatively minor exception, the validity of the Commonwealth Act was upheld. The Western Australian Act was declared invalid on the grounds of inconsistency with both Commonwealth Acts. As far as Commonwealth power was concerned, the case established that the 'races' power could support legislation of this kind, at least. It thus paved the way for the later decision in Kartinyeri that, except perhaps in extreme circumstances, it is for parliament to determine whether a special law is deemed necessary. The court rejected an argument that the proportion of the State land mass affected by the Commonwealth Act made the Act a discriminatory measure against Western Australia which rendered it invalid in accordance with prevailing principles of intergovernmental immunity. In rejecting the latter argument, the court relied on the familiar if artificial doctrine that the immunities principles protect only States as 'bodies politic' rather than their powers, specifically or in general. ${ }^{17}$ The outcome of this typical struggle over power and policy between the Commonwealth and the States was to preserve the rights of a small indigenous minority which cannot hope to secure sufficient political power to protect its own interests from the nonindigenous majority.

The Native Title Act assumed what Mabo did not decide: that leases, including pastoral leases, extinguished native title to land. In the Wik case, in the context of pastoral leases in Queensland, a majority of the High Court held that this was not so as long, at least, as particular native title rights were capable of being exercised consistently with the terms of a pastoral lease. The furore that followed this decision was equal to, if not greater than, that which accompanied Mabo itself. On this occasion, however, the incumbent Commonwealth government, representing the national majority, sought greater limitation of native title rights. This involved, in particular, enhanced authority for the States to impose their own native title regimes as long as these were consistent with prescribed national standards. The eventual form of the legislation was tempered in its passage through the Senate by concessions to Senator Harradine from Tasmania who held the balance of power. These broadened, to a degree, the right of indigenous groups to negotiate in relation to development on some native title lands and strengthened the criteria for State and 
Territory native title regimes (ATSIC 1998a). Critically, they enabled either house of the parliament to disallow a determination by the Commonwealth minister, approving a State or Territory regime (Native Title Act 1993 , ss. 43A, 214). This paved the way for action subsequently taken by the Senate, to disallow the first such determination, in relation to the Northern Territory (Commonwealth Parliament 1999:1609). The effect was to leave in place, for the moment, the provisions of the Commonwealth Act.

Courts have played a key role in the history of the evolution of the constitutional position of the indigenous peoples of Australia. Courts gave the imprimatur to the doctrine of terra nullius in the nineteenth century. Appropriately, in these circumstances, a court was instrumental in repudiating the doctrine, thus casting doubt on its legitimacy from the start. Given the controversial nature of the issue, it is unlikely that governments and parliaments could have been persuaded to act so definitively. The preparedness of the High Court to do so, when the rights of a small minority were at stake, is a tribute to the value of judicial independence. The cost has been a new political interest in the function and composition of the High Court, which may be felt for some time to come.

Neither Mabo nor Wik were constitutional cases. The longer-term effectiveness of both, however, has been closely interwoven with the constitution. While there are no constitutional restrictions on State power to resume lands that are subject to native title, States must act consistently with Commonwealth legislation, including, for this purpose, the Racial Discrimination Act 1975. The Commonwealth itself is unable to override native title without compensation, because one of the rare constitutional limits on Commonwealth power precludes legislation with respect to the acquisition of property other than on 'just terms' (s. 51(31)). The Commonwealth can, of course, repeal or amend the Racial Discrimination Act, freeing the way for the States to act, but is inhibited from doing so by international opinion.

The courts were not the sole actors in these developments, however. On the contrary, legislation was necessary after Mabo to provide an effective framework for the adjudication of claims. The legislation required amendment again after Wik. In this context also, the effect of federalism was felt, through the influence of the Senate on legislation that was passed and on the way in which it has operated since.

\section{ASPECTS OF SELF-GOVERNMENT}

Aboriginal people constitute less than 2 per cent of the Australian population. Even with the wider opportunities for representation that a federal system offers, they are unlikely to have a substantive impact on public policy through general democratic processes. In fact, it has been relatively rare for indigenous Australians to hold elected public office at 
all, in either the Commonwealth or the States. Nor has there ever been substantial support for specific indigenous representation, the example of New Zealand notwithstanding. With a few notable exceptions, therefore, at Commonwealth, State and Territory and even local levels of government, indigenous Australians are subject to policies and laws made and administered by non-indigenous Australians. The problem is compounded by significant differences in the interests and preferences of indigenous and non-indigenous peoples, not only in relation to land but also in matters of language, culture and law.

Various institutions have been established from time to time to provide indigenous people with a limited measure of control over their own affairs. These include land councils, created in association with land rights legislation to represent Aboriginal groups on land rights claims. More generally, some jurisdictions have facilitated Aboriginal self-governance at the local government level or on areas owned by Aboriginal communities.

The most substantial venture so far, however, was the establishment of ATSIC by the Aboriginal and Torres Strait Islander Commission Act 1989. The objects of the Act refer to 'maximum participation' of indigenous peoples 'in the formulation and implementation of government policies that affect them'; promotion of 'self-management and self-sufficiency'; and coordination of policies affecting indigenous peoples between the levels of government 'without detracting from the responsibilities' of each. To this end, the Act provides for thirty-five elected regional councils, organised within seventeen zones, each of which elects a commissioner to ATSIC itself. The functions of ATSIC range from the formulation and implementation of programs to advice to the government on indigenous affairs (s. 7). Its actual authority to design and implement programs, however, depends on a conferral of specific functions, by the prime minister in relation to Commonwealth matters or by individual State and Territory governments in relation to matters within their usual sphere of responsibility (ss. 8 and 9 ).

The Aboriginal and Torres Strait Islander Commission has been a controversial body since its establishment. Even within the indigenous community, it has encountered some resistance. While ATSIC commissioners are, for the most part, elected, they are not always or necessarily people who enjoy traditional respect within Aboriginal culture. Nor do ATSIC areas necessarily coincide with tribal boundaries. From the outset, there was some opposition to ATSIC from non-indigenous Australians, as a government body with responsibilities only to one community. In time, however, other difficulties emerged, reflecting the unusual character of ATSIC itself. It is an elected body which combines both policy-making and administrative functions. It is established as an independent statutory corporation but necessarily doubles also as a source of advice to the Commonwealth minister, in the manner of a department. The minister has 
some powers in relation to ATSIC, including a power to issue general directions (s. 12), but lacks the full authority generally wielded by a minister in relation to a department of state. With hindsight, insufficient thought was given to the way in which a body of this kind would fit within an otherwise typically Westminster style of parliamentary government and administration, particularly when indigenous policy issues became sensitive, from the standpoint of the government of the day.

The results have included a series of controversies involving ATSIC on grounds of actual or perceived waste and mismanagement; the development of a separate source of policy advice to government on indigenous affairs, in the Department of Prime Minister and Cabinet; and the removal from ATSIC of functions in key areas, including indigenous education and health. Nor has ATSIC been entirely successful in coordinating activities across levels of government (ATSIC 1998b), despite a 'national commitment' endorsed by the Council of Australian Governments in 1992, ${ }^{18}$ and despite ATSIC participation in the intergovernmental ministerial council dealing with indigenous affairs. ${ }^{19}$

The future of ATSIC is not entirely clear. It is likely to be retained, however, and gradually to stabilise and to become more widely accepted. It would be a pity if it were otherwise. The concept of an indigenous structure for policy development and service delivery seems correct in principle. It would be unrealistic to have expected that such an innovative and challenging idea would be implemented without difficulty the first time around.

ATSIC alone has not stilled a wider debate on self-government or selfdetermination. The debate is conducted at two levels. The first concerns sovereignty or self-determination in the sense in which this term is used in article 1 of the International Covenant on Civil and Political Rights: the right of peoples to 'freely determine their political status and freely pursue their economic, social and cultural development'. It takes its character in Australia from the ambiguous nature of the original European settlement. It is reinforced by the treatment of indigenous Australians as inferior citizens for most of the history of federated Australia. Taken to its extreme, it has implications for the cohesion of Australia itself as a nation-state.

The second level of the debate is practical and concerns the degree of effective self-government that is available to indigenous people. This has been variously described as self-management (House of Representatives Standing Committee on Aboriginal Affairs 1990:4) and self-sufficiency (Aboriginal and Torres Strait Islander Commission Act 1989), as well as self-government (Gardiner-Garden 1994:36). It is complicated by the impossibility of a single, uniform solution, suiting the circumstances of both urban and traditional indigenous groups and of groups in both the 
settled south and more sparsely populated north of the country. ATSIC has made an important contribution to self-government in this sense and may have further potential still, if its operations are effectively decentralised. Its functions and jurisdiction are too limited, however, to fully meet the demand.

Part of the demand stems from a desire of some groups for the recognition, at least in part, of indigenous customary law. It is clear that an extensive range of customary laws existed at the time Australia was settled. It is also clear that customary law continues to apply in many indigenous communities, often in an uneasy relationship with the general law. The failure of general law to recognise and appropriately accommodate customary law contributes to the destabilisation of indigenous communities and is not conducive to respect for either law, on the part of indigenous people.

The result is clearly unsatisfactory; the solution in policy terms, however, is less obvious. Customary laws differ between indigenous groups. Not all indigenous people wish to be subject to customary law. Some customary laws may be inconsistent with norms that, for one reason or another, should be applicable to all Australians. It is at this point that the debate on customary law links with the question of self-government for particular communities. In theory, at least, it would be possible to devise self-government arrangements which included provision for the application of customary law, in defined subject areas or subject to overriding national and international standards. The Charlottetown Accord, put to referendum in Canada in 1992, provided a possible model for this purpose..$^{20}$

While there has been some talk about these issues, so far there has been little action. In theory, opposition to indigenous self-government should be more muted in a federal system, which by definition involves divided sovereignty. Nevertheless, discussion of self-government, in the sense of greater autonomy, inevitably founders on concerns about sovereignty, whether real or feigned. The concept of self-government for indigenous Australian communities is unlikely to be taken seriously until the two levels of the debate on indigenous autonomy are clearly distinguished and better understood.

\section{THE FUTURE}

There are two particular developments that could beneficially affect the constitutional position of indigenous Australians in the future. Both have been focused on the constitutional centenary in 2001.

\section{The Northern Territory}

Indigenous people comprise approximately 25 per cent of the population of the Northern Territory. This is the largest indigenous proportion 
of population in any Australian jurisdiction. At the time of federation, the Northern Territory was part of the State of South Australia. It was transferred to the Commonwealth in 1911. The Territory achieved selfgovernment in 1978 along lines that mirrored the position of the States, while falling short of the degree of autonomy that the States enjoy as constituent units of the federation.

For some time, the Northern Territory has been seeking statehood. Symbolically, the constitutional centenary has been an appropriate target. A 1996 draft of a statehood constitution provided for the recognition of Aboriginal customary law, in two separate versions. Alternative 1 restricted the use of customary law to circumstances where it would be implemented and enforced as part of the common law or the practice of the courts. Alternative 2 would have gone further, to enable customary law to be implemented and enforced in respect of any person who considers that he or she is bound by the law. The Northern Territory constitutional committee noted that 'no Australian jurisdiction has ever legally recognised the system of customary law operating amongst its indigenous inhabitants'. It also noted, however, that it had encountered 'no significant opposition to some form of recognition'. ${ }^{21}$ The draft also would have provided for a repatriated Aboriginal Lands Act, entrenched by organic law, and would have recognised (if this was necessary) that the Northern Territory legislature might provide for Aboriginal self-determination.

Political controversy over the constitutional convention held to consider the draft and over the terms of the subsequent referendum caused the latter to fail. Indigenous Territorians were among its opponents. One reason lay in the convention's attitude to recognition of Aboriginal customary law. The proposals in the original draft were reduced to a limited form which would have required the parliament of the new Territory to enact customary law within five years, an impracticable feat which in any event was unacceptable to indigenous Australians (Heatley and McNab 1998:155).

This is not necessarily the end of the drive for statehood. In separate constitutional conventions, held before and after the referendum vote, the indigenous people set out their demands for a statehood constitution..$^{22}$ These included recognition of Aboriginal law as a source of law, operating through Aboriginal structures of law and governance; protection of indigenous rights and development of a framework for self-government; and more general constitutional initiatives, such as protection of human rights, effective separation of powers, and, perhaps, an electoral system based on proportional representation. While these demands are unlikely to be satisfied in full, they offer a base on which further negotiations might proceed. These negotiations will be delicate: the referendum was defeated by a relatively small margin and another round, with a more sophisticated process, could see it passed without substantial 
improvement in its application to indigenous Territorians. Even then, all would not be lost. The terms of statehood for the Northern Territory must be acceptable to the Australian parliament, including the Senate, where senators holding the balance of power presently are sympathetic to indigenous interests.

\section{Reconciliation}

To further reconciliation, the Commonwealth established in 1991 a Council for Aboriginal Reconciliation. One of the functions conferred on the council was to consult indigenous communities and the Australian community as a whole 'on whether reconciliation would be advanced by a formal document or documents of reconciliation' (Council for Aboriginal Reconciliation Act 1991, s. 6). In 1999, the council released for public consultation a draft Document for Reconciliation and four supporting draft strategies. The document itself refers, inter alia, to respect for 'the right of Aboriginal and Torres Strait Islander peoples to determine their own destinies'. The draft strategies refer to the right of indigenous Australians 'to participate, as they choose, in all levels of decision-making on matters which affect them and their communities' and to their 'continuing aspirations for greater recognition and self-determination within the framework of the Australian Constitution'. ${ }^{23}$ They also contemplate recognition and protection of the declaration in the constitutions of the Commonwealth and the States. ${ }^{24}$

There may be no substantive decision on the declaration and supporting strategies before the constitutional centenary in 2001. In any event, they would be likely to be no more than another small step in improving the actual and symbolic position of indigenous Australians within the polity as a whole. Meanwhile, the prospect of a link between the declaration and the Commonwealth constitution has been complicated further by the 1999 proposal to add a preamble to the constitution. The preamble would have included a statement 'honouring Aborigines and Torres Strait Islanders, the nation's first people, for their deep kinship with their lands and for their ancient and continuing cultures which enrich the life of our country' (Constitution Alteration (Preamble) 1999). The proposal was put to referendum on 6 November 1999, but rejected. While many Aboriginal groups were opposed to the wording and advocated a 'no' vote, the fact of rejection is discouraging to the extent that it is likely to deter other attempts at constitutional change in the future.

\section{CONCLUSION}

The accommodation of indigenous people in constitutional systems is an issue for the end of the twentieth century. At stake is the right of indigenous people to live in a way which is guided by their own cultural practices 
under their own leaders, albeit within a wider framework of norms applicable to the whole community.

In principle, federations have an advantage in dealing with this issue. Federations are based upon the concept of divided sovereignty. They accommodate diversity. They offer an opportunity for experimentation through competition between jurisdictions. They enable innovation in smaller jurisdictions by means of which the larger national majority may be persuaded.

Nevertheless, federations find it difficult to deal adequately with the needs of their indigenous people. For the most part, federations offer diversity only on a geographic basis, which may or may not coincide with ethnicity. It is rare for indigenous groups to be geographically concentrated, Nunavut notwithstanding. Liberal democratic values make even federations loath to cut across geographic divisions to single out a particular group. Significant differences between the cultures of indigenous peoples and that of the general community are likely to be an additional barrier in practice. And in these increasingly multicultural times, indigenous demands often are echoed by demands for distinctive treatment from other ethnic communities as well.

The adaptability of federal forms to deal with indigenous issues varies between federations. In many ways, the Australian federation has been particularly unreceptive. The original doctrine of terra nullius encouraged belief that Aboriginal law and culture was inferior. The colonies which later became States and which are responsible for many of the areas of governance relevant to indigenous people were late to recognise them as equal citizens. The Commonwealth acquired its authority in relation to indigenous Australians after federation was far advanced. The scope of Commonwealth power was ambiguous from the start. Indigenous Australians became the victims of the buck-passing and irresponsibility that often is associated with concurrent federal powers. Their cause became even more controversial through entanglement with other intergovernmental disputes, including the scope of the external affairs power and the degree of protection that the constitution gives one government from another.

The Commonwealth has been a relatively more enlightened level of government for indigenous Australians. Even here, however, voters and politicians have resisted claims for autonomy of the most limited kind. This is partly the result of assumptions entrenched by the apparent homogeneity of the Australian population since European settlement. It is partly because the political system is strongly majoritarian and uneasy with compromise and consensus. Despite its federal institutional structure, Australian federalism has suffered from the lack of a federal culture, receptive to power sharing. The capacity of the federal system to respond to the needs of indigenous people is hampered for this reason as well. 


\section{NOTES}

1 Krugerv. Commonwealth (1997) 190 CLR 1.

2 Cooperv. Stuart (1889) 14 App. Cas 286.

3 For example, Land Act 1933 (WA), s. 106.

4 Mabo (No. 2) (1992) 175 CLR 1.

5 Aboriginal Land Rights (Northern Territory) Amendment Act (No. 3) 1978 (Commonwealth): Commonwealth Parliamentary Debates, House of Representatives 109, 31 May 1978, 2820 (Staley).

6 Kartinyeri v. Commonwealth (1998) 72 ALJR 722, 732 per Gaudron J, 760 per Kirby J.

7 Statute of Westminster Adoption Act 1942 (Commonwealth).

8 Koowarta v. Bjelke-Petersen (1982) 153 CLR 168.

9 Cooperv. Stuart (1889) 14 App. Cas 206.

10 Milimpum v. Nabalco Pty Ltd (1971) 17 FL.R 141.

11 The findings of Moynihan J are summarised in the judgment of Brennan J in Mabo (No. 2):17-20.

12 Mabov. Queensland (No. 1) (1988) 166 CLR 186.

13 Mabov. Queensland (No. 2) (1992) 175 CLR 1, 15, Mason CJ and McHugh J.

14 Wikv. Queensland (1996) 187 CLR 1.

15 One lurid example: Mabo 'carried the seeds of the territorial dismemberment of the Australian continent and the end of the Australian nation as we have known it' (quoted in Gardiner-Garden 1994:143, 165).

16 Western Australia v. Commonwealth (1995) 183 CLR 373, 483.

17 Ibid., 479, 480.

18 National commitment to the improvement of outcomes in the delivery of services for Aboriginal people and Torres Strait Islanders.

19 Ministerial Council on Aboriginal and Forres Strait Islander Affairs (MCATSIA).

20 The Accord was rejected at referendum. Had it succeeded, it would have added new provisions to the Canadian Constitution Act 1982, recognising the 'inherent right of self-government' of the aboriginal peoples within Canada, including the possible application of aboriginal law.

21 Legislative Committee of the Northern Territory, Sessional Committee on Constitutional Development, Foundations for a Common Future, vol. 1, November 1995:5-6.

22 Combined Aboriginal Nations of Central Australia held a convention at Kalkaringi in August. The Northern Territory Aboriginal Nations held a convention in Batchelor in December.

23 Draft National Strategy to Promote Recognition of Aboriginal and Torres Strait Islander Rights.

24 Draft National Strategy to Sustain the Reconciliation Process.

\section{REFERENCES}

ATSIC (Aboriginal and Torres Strait Islander Commission) 1995. Recognition Rights and Reform. Canberra: ATSIC.

1998a. 'Detailed analysis of Native Title Amendment Act 1998' (October), <http://www.atsic.gov.au/issues/native_title.htm>. 
1998b. Annual Report 1997-98. Canberra: ATSIC.

Bonner, Neville T. 1994. 'Introduction', in Mabo Papers. Parliamentary Research Service Subject Collection No. 1. Canberra: Australian Government Publishing Service.

Chesterman, John and Brian Galligan 1997. Citizens without Rights. Cambridge: Cambridge University Press.

Commonwealth Parliament 1999. Senate Journal. 31 August.

Coonan, Helen 1999. 'The Senate: safeguard or handbrake on democracy', The Sydney Papers 11(1), Summer.

Gageler, Stephen 1998. 'The races power problem: the case for validity, Public Law Review 9.

Gardiner-Garden, John 1994. 'Aboriginality and Aboriginal rights in Australia', in Mabo Papers Parliamentary Research Service Subject Collection No. 1. Canberra: Australian Government Publishing Service.

Heatley, Alastair and Peter McNab 1998. 'The Northern Territory Statehood Convention 1998', Public Law Review 9.

House of Representatives Standing Committee on Aboriginal Affairs 1990. Our Future, Our Selves: Aboriginal and Torres Strait Islander Community Control, Management and Resources. Parliamentary Paper No. 137.

Kickingbird, Kirke 1993. 'The constitutional settlement', in Council for Aboriginal Reconciliation, The Position of Indigenous People in National Constitutions. Canberra: Australian Government Publishing Service.

Lindell, Geoffrey 1998. 'The races power problem: other observations', Public Law Review 9.

Nicholson, G.R. 1985. 'The constitutional status of the self-governing Northern Territory', Australian Law Journal 59:698.

Reeves, John, QC 1998. Building on Land Rights for the Next Generation: The Review of the Aboriginal Land Rights (Northern Territory) Act 1976. 2nd edn. Canberra: Australian Government Publishing Service. 


\section{University Library}

\section{- M M I N E R VA A gateway to Melbourne's research publications}

Minerva Access is the Institutional Repository of The University of Melbourne

Author/s:

Saunders, C

Title:

The Implications of Federalism for Indigenous Australians

Date:

2000

Citation:

Saunders, C. (2000). The Implications of Federalism for Indigenous Australians. Ghai, Y (Ed.). Autonomy and Ethnicity: Negotiating Competing Claims in Multi-Ethnic States, (1), pp.266-286. CUP.

Persistent Link:

http://hdl.handle.net/11343/297264 